\title{
A BRAMBLING AT CLARESHOLM, ALBERTA DURING WINTER 1993-1994
}

\author{
JASON ATTWELL, Box 2015, Claresholm, AB. TOL OT0 and PETER \\ SHERRINGTON, RR 2, Cochrane, AB. TOL OWO
}

During the winter of 1993-1994, a Brambling was present for 101 days in a backyard in Claresholm, Alberta. Throughout this period it was observed almost daily by Attwell and its feeding behaviour and interactions with other species were noted.

The Brambling is a palearctic finch breeding mainly in subarctic and boreal birch woods from Scandinavia across central Russia to Kamchatka. ${ }^{1,2}$ The species winters entirely south of its breeding range, concentrating in areas with abundant beechnuts, sometimes in spectacular numbers. ${ }^{1}$
In North America, the Brambling is a rare but regular spring and fall migrant in the western Aleutian Islands of Alaska ${ }^{3}$ but was not recorded outside Alaska until 1958, in New Jersey. ${ }^{4}$ The first Canadian Record was 7 February 1971 on the Queen Charlotte Islands of British Columbia and subsequently the number of records of the species has increased significantly across the continent. ${ }^{4}$ On 14 November 1989 Alberta recorded its first Brambling when a male visited a feeder at Edson where it remained until at least the end of January $1990 . .^{5}$

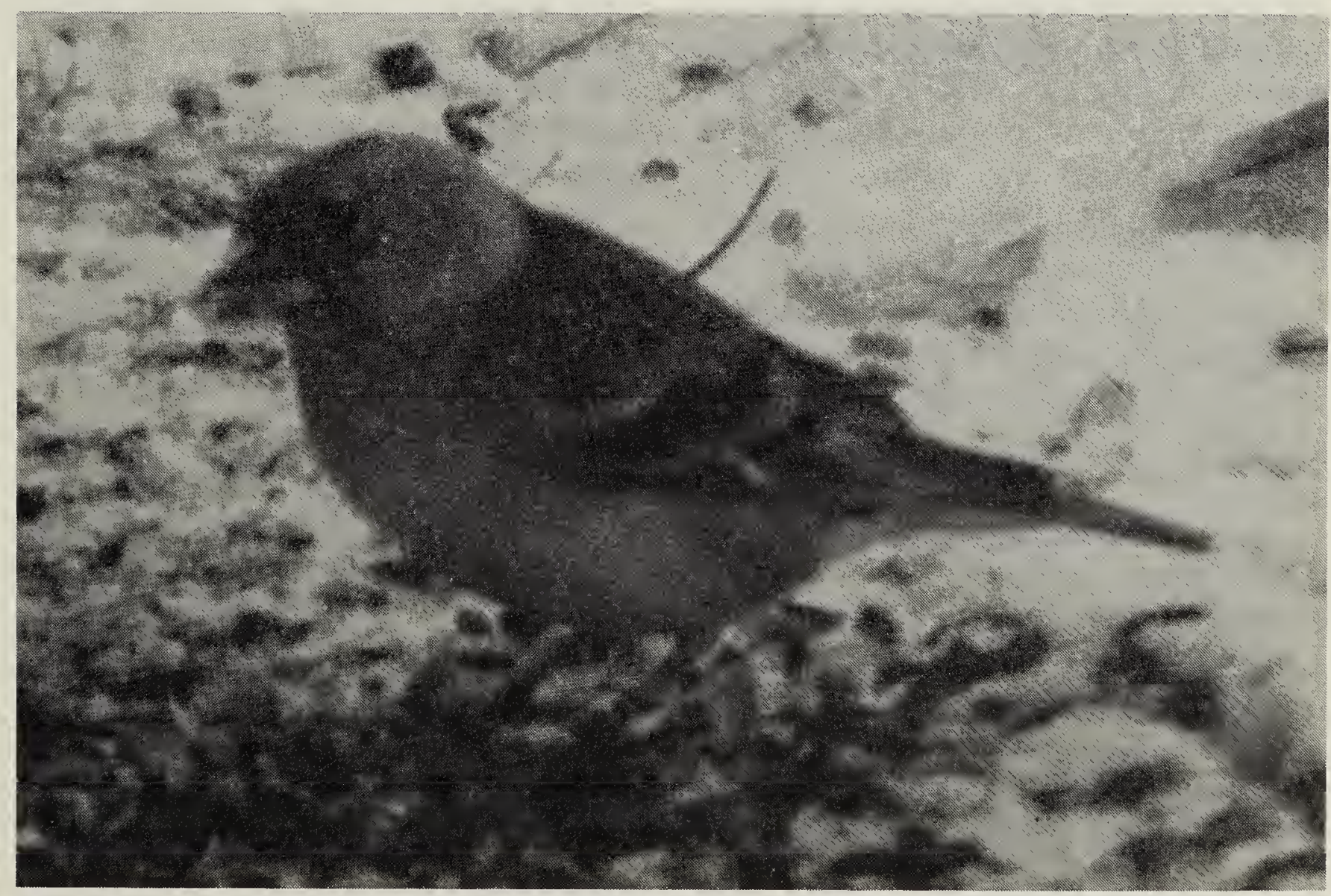

Adult female Brambling at Claresholm, Alberta, December 1993

Grace Norgard 


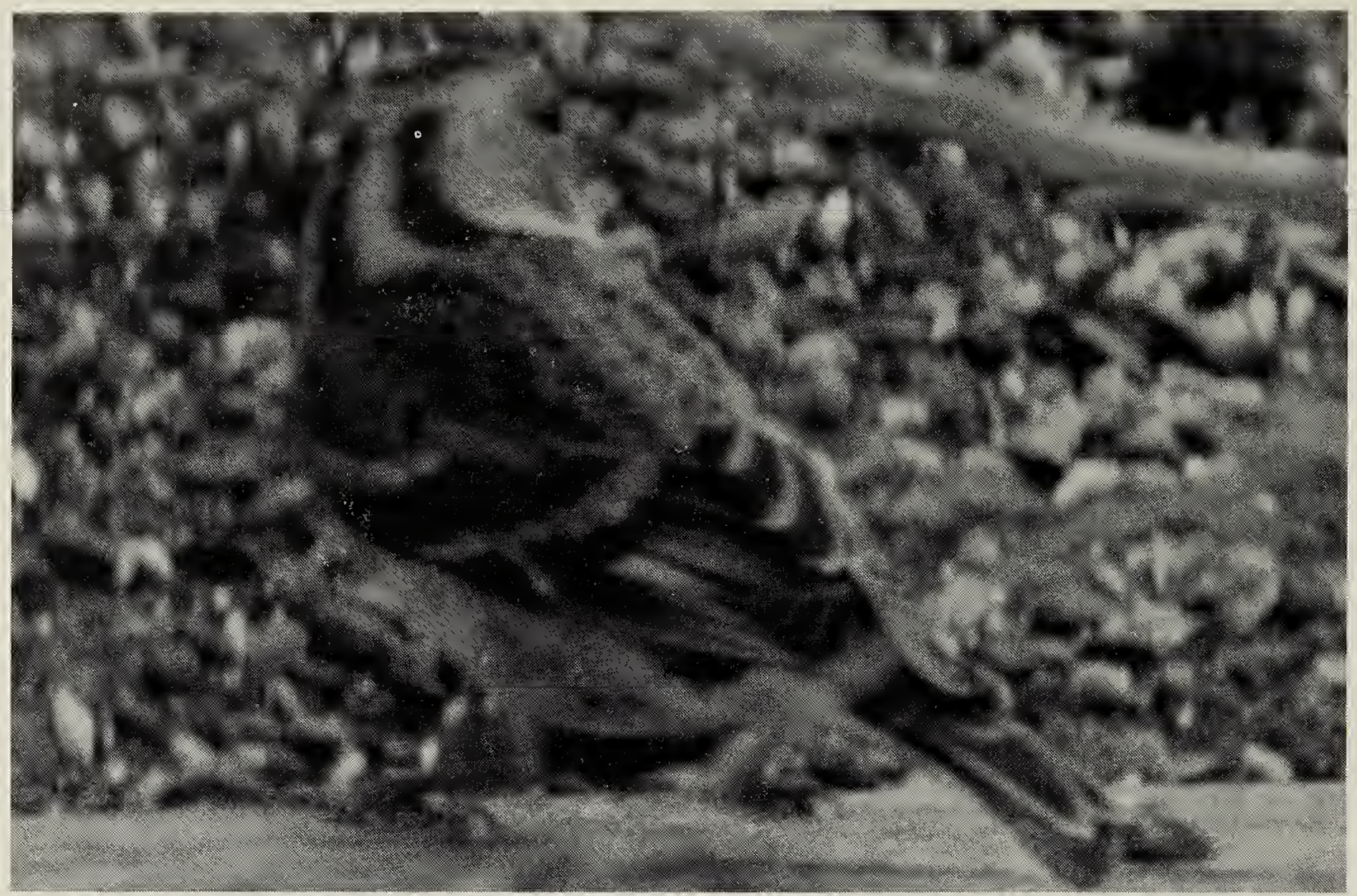

Adult female Brambling at Claresholm, Alberta, December 1993

Grace Norgard

The second Alberta Brambling was first seen in the backyard of Jason and Ruth Attwell in Claresholm on 19 December 1993 high in a Green Ash (Fraxinus pennsylvanica) with a Common Redpoll and a Yellowrumped [Myrtle] Warbler (itself a rare wintering bird in Alberta that had been present since mid-October and which survived the entire winter). The Brambling remained in the area for 101 days and was last seen on 29 March 1994. During this time the bird was seen by nearly 100 people and excellent photographs were obtained.

The bird's pale grey face with darker auricular patch, broad rufouscinnamon tips to the greater coverts and white belly and rump, untinged with yellow, identified the bird as a winter plumaged adult female. ${ }^{2}$ By the end of March, abrasion of the lighter feather tips of the black- centred feathers of the cap, nape and back had more clearly defined these areas and when the bird departed it was essentially in its summer breeding plumage. The bird was not heard to make any sound during its stay.

Although a wide variety of feeder and natural foods were available in the yard, the bird showed a consistent preference for both certain food types and location. In terms of time, approximately $50 \%$ of the bird's observed feeding involved plant material (mainly seeds) and 50\% invertebrate animal material (insects, arthropods, animal fat).

About half the observed feeding took place at a low feeding tray where the bird exclusively took small black oil sunflower seeds. Sunflower seed, niger seed and wheat were also available at seven other feeders placed above the ground but the bird was never observed feeding there. Occasionally the bird was observed feeding on crab apples (Malus pumila var.) both on trees and on the ground, although it is uncertain whether the fruit was being eaten or 
insects being gleaned from the fruit. The fruits of chokecherry (Prunus virginiana), cotoneaster (Cotoneaster $s p$.) and mountain ash (Sorbus americana) were widely available but were never seen to be taken by the bird. This is consistent with feeding behaviour in Europe where Bramblings take few seeds from fleshy fruits, ${ }^{6}$ with the exception of the flesh and seeds of European mountain ash (Sorbus aucaparia), ${ }^{2}$ good crops of which can concentrate flocks of the bird. ${ }^{7}$

Approximately $35 \%$ of the feeding behaviour comprised ground feeding, mainly in leaf-litter beneath hedges and trees where the bird would move leaves with its beak presumably searching for insects and arthropods. The bird was never seen to use its feet to assist in this operation. Throughout the winter the bird also gleaned the bark of tree branches well above the ground. This element of its diet was supplemented through visits to a $50 \%$ mixture of peanut butter and ground suet set on a post $1.5 \mathrm{~m}$ above the ground. Approximately $15 \%$ of the bird's observed feeding took place here. A heated birdbath was present near the main feeding area to which the Brambling came to drink many times a day but was never seen to bathe.

A total of 19 other species of birds were present in the yard during the winter and most appeared tolerant of the Brambling at the feeding station. Initially House Sparrows would chase her away from the feeder but soon ignored her. In late January there was an influx of 70 Common Redpolls into the yard that proved to be dominant at the feeding area, consistently driving the Brambling away. Another similar feeding area was established $20 \mathrm{~m}$ away where the bird fed with less disturbance. At this time she ceased to eat the suet/peanut butter blend. The reason for this is unclear, but it was not because of competition with redpolls as they rarely took this food.

There was relatively little snow throughout the winter but in February temperatures dropped on occasion to $-30^{\circ} \mathrm{C}$. On 28 February a prolonged period of chinook winds began and the yard was cleared of snow within three days. Half the redpolls left the area and the Brambling made less frequent visits to the feeding area, preferring instead to forage and glean under trees and hedges. The lack of snow presumably made such foraging easier and the higher temperatures would have resulted in a greater abundance and mobility of invertebrate food. Drinking at the heated birdbath was confined during this period to a short period about one hour after first light. On 12 March the rest of the redpolls departed and immediately the Brambling resumed feeding and drinking throughout the day at the main feeding area until her departure on the night of 29 March.

During the winter of 1993-1994, 12 Bramblings were recorded in North America at nine localities. ${ }^{4}$ Those closest to the Claresholm bird were one at Portage la Prairie, two near Minnedosa, Manitoba and one near Kalispell, Montana. ${ }^{8,9}$ This was the fourth highest Brambling "invasion" year to date; the highest involved 17 records of the species outside of Alaska in the winter of 1983-1984.

1. NEWTON, I. 1972. Finches. Collins, London.

2. CRAMP, S. and C.M. PERRINS 1994. Handbook of the birds of Europe, the Middle East and North Africa. Volume VIII. Crows to Finches. Oxford University Press, Oxford. 
3. ROBERSON, D. 1980. Rare birds of the West Coast. Woodcock Publications, Pacific Grove, California.

4. JONES, C. 1995. A review of North American Brambling records. Birders Journal 4:75-79.

5. KOES, R. and P. TAYLOR, 1990. American Birds 44:111, 285.

6. SNOW, B. and D. SNOW, 1988. Birds and berries. T\&AD Poyser, Calton.
7. ERIKKSSON, K. 1970. Wintering and autumn migration ecology of the Brambling Fringilla montifringilla. Sterna 9:77-90.

8. KOES, R. 1994. Birders Journal 3:16, 85.

9. SWINGEN, D. and T.H. ROGERS, 1994. National Audubon Society Field Notes 48:229, 322.

\section{POETRY}

\section{GRAIN EXCHANGE}

Kilograms of crushed corn

seeds of sunflowers

disappear from feeders

like dinner from a plate,

fill insatiable reservoirs

of chickadee and jay,

redpoll, sparrow, siskin.

Entertain us with your antics now,

sing arias in spring.

In summer's heat

make meat of garden pests

till autumn's chill

triggers our instincts

to fill your feeders again.

- Judith Benson, 1048 Spadina Crescent E., Saskatoon, SK. S7K 3H7 